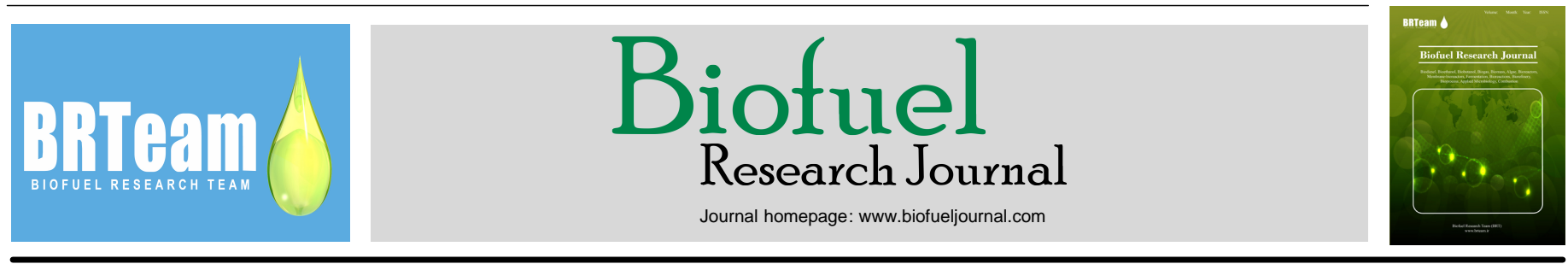

Review Paper

\title{
A critical review on biomass gasification, co-gasification, and their environmental assessments
}

\author{
Somayeh Farzad*, Mohsen Ali Mandegari, Johann F. Görgens
}

Department of Process Engineering, University of Stellenbosch, Private Bag X1, Matieland, 7602, South Africa.

\section{HIGHLIGHTS}

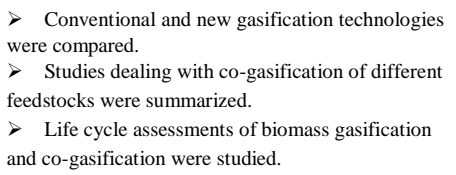

$>$ Conventional and new gasification technologies were compared.

$>$ Studies dealing with co-gasification of different feedstocks were summarized.

$>$ Life cycle assessments of biomass gasification and co-gasification were studied.

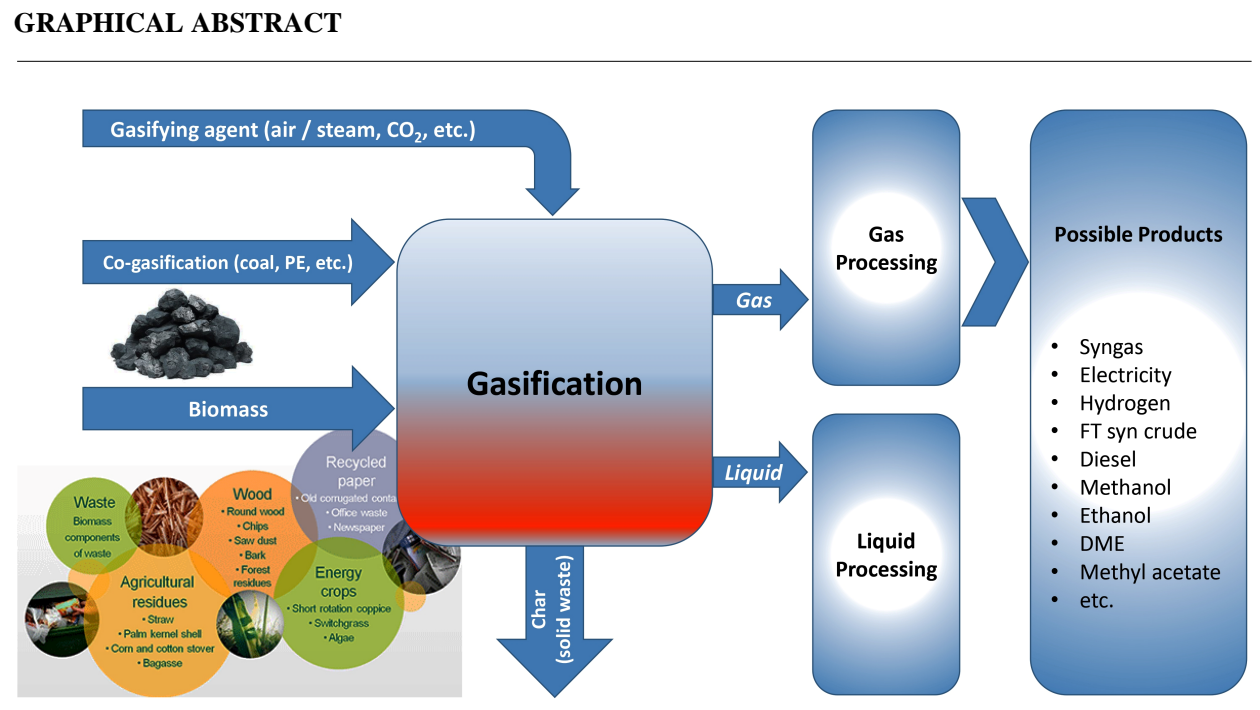

\section{ARTICLE INFO}

\section{Article history:}

Received 11 August 2016

Received in revised form 30 August 2016

Accepted 15 September 2016

Available online 1 December 2016

\section{Keywords:}

Biomass gasification

Plasma gasification

Supercritical water gasification

Co-gasification

Life Cycle Assessment (LCA)

\begin{abstract}
Gasification is an efficient process to obtain valuable products from biomass with several potential applications, which has received increasing attention over the last decades. Further development of gasification technology requires innovative and economical gasification methods with high efficiencies. Various conventional mechanisms of biomass gasification as well as new technologies are discussed in this paper. Furthermore, co-gasification of biomass and coal as an efficient method to protect the environment by reduction of greenhouse gas (GHG) emissions has been comparatively discussed. In fact, the increasing attention to renewable resources is driven by the climate change due to GHG emissions caused by the widespread utilization of conventional fossil fuels, while biomass gasification is considered as a potentially sustainable and environmentally-friendly technology. Nevertheless, social and environmental aspects should also be taken into account when designing such facilities, to guarantee the sustainable use of biomass. This paper also reviews the life cycle assessment (LCA) studies conducted on biomass gasification, considering different technologies and various feedstocks.
\end{abstract}

* Corresponding author at: Tel.: +27 218089485

E-mail address: sfarzad@ sun.ac.za

Please cite this article as: Farzad S., Mandegari M.A., Görgens J.F. A critical review on biomass gasification, co-gasification, and their environmental assessments. Biofuel Research Journal 12 (2016) 483-495. DOI: 10.18331/BRJ2016.3.4.3 


\section{Contents}

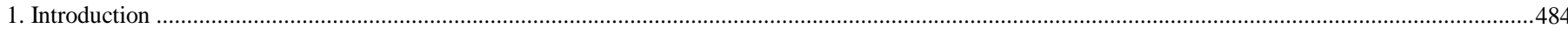

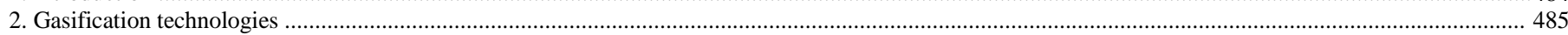

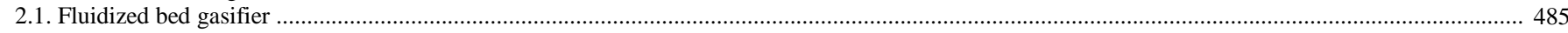

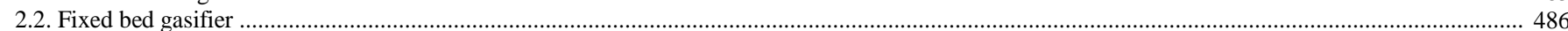

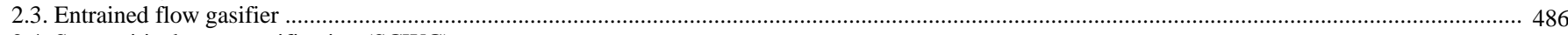

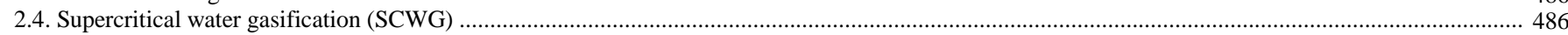

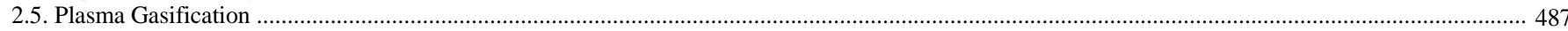

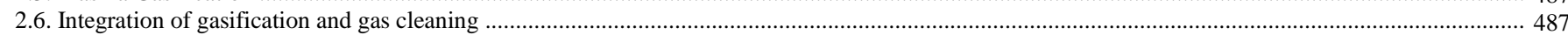

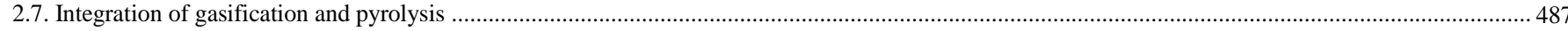

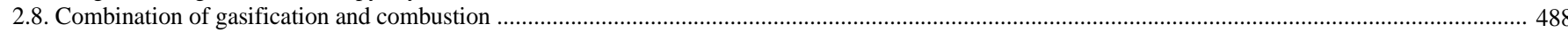

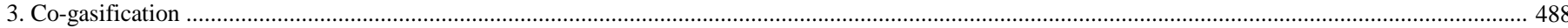

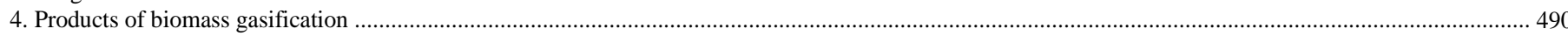

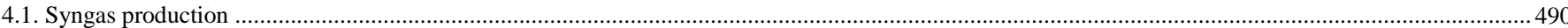

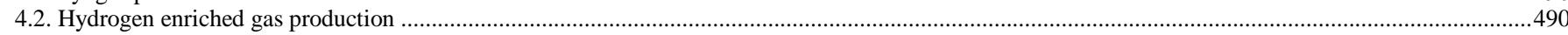

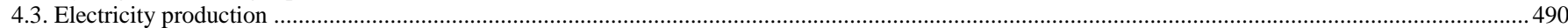

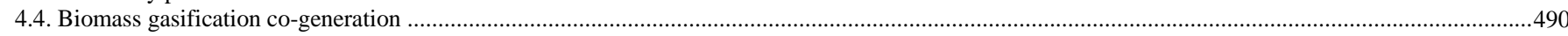

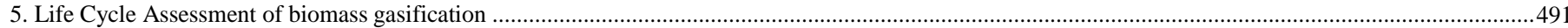

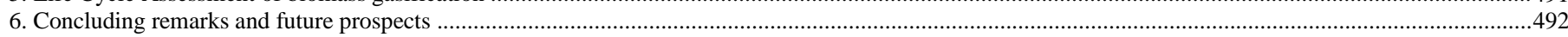

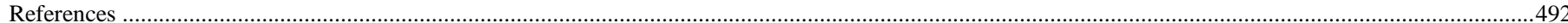

\begin{tabular}{|ll|}
\hline Abbreviations & \\
AC & Alternating current \\
AER & Absorption enhanced reforming \\
BIG-GT & Biomass integrated gasification/gas turbine \\
BFD & Bubbling fluidized bed \\
CFD & Circulating fluidized bed \\
CHP & Combined heat and power \\
CLC & Chemical loop combustion \\
CSCWG & Catalytic supercritical water gasification \\
DC & Direct current \\
DFBG & Dual fluidized-bed biomass gasifiers \\
DME & Dimethylether \\
ECN & Energy Research Center of the Netherlands \\
FBG & Fluidized bed gasifier \\
F-T & Fischer-Tropsch \\
GHG & Greenhouse gas \\
HHV & High heating value \\
IEA & International energy agency \\
ISO & International Organization for Standardization \\
IGCC & Integrated gasification combined cycle \\
LCA & Life cycle assessment \\
LHV & Lower heating value \\
ORC & Organic Rankine cycle \\
PSA & Pressure swing adsorption \\
PSI & Paul-Scherrer Institute \\
RF & Radio frequency \\
RPM & Random pore model \\
SCWG & Supercritical water gasification \\
SNG & Synthetic natural gas \\
S/B ratio & Steam-to-biomass (S/B) ratio \\
WGSR & Water-gas shift reaction \\
& \\
\hline
\end{tabular}

\section{Introduction}

Climate change phenomenon or the global temperature rise caused by the emissions of $\mathrm{CO}_{2}, \mathrm{NO}_{x}$, and $\mathrm{SO}_{\mathrm{x}}$ pose a serious threat to mankind and the other species. According to the international energy outlook (www.eia.gov), world energy related $\mathrm{CO}_{2}$ emissions will increase from 30.2 (in 2008) to 43.2 billion metric tons in 2035. Since greenhouse gas (GHG) emissions from burning fossil fuels for power generation is a major contributor to climate change, a switch from conventional to renewable power resources, i.e., biomass, solar, wind, and hydroelectric energy generation, is vital (Sikarwar et al., 2016).

Biomass has an advantage over the other renewable sources as it is more evenly distributed over the earth and is also abundantly available (Akia et al.,
2014; Din and Zainal, 2016; Gottumukkala et al., 2016). In fact, biomass is the fourth-most important source of energy after coal, petroleum, and natural gas, and currently provides more than $10 \%$ of the global energy (Saidur et al., 2011). It is estimated that biomass and waste will contribute a quarter or third of global primary energy supply by 2050 (Bauen et al., 2009).

The first confirmed application of gasification for electricity production was reported in 1792. However, the first successful gasifier unit was installed in 1861 by Siemens, while the fluidized bed gasifier (FBG) was only developed in 1926, leading to the establishment of the first commercial coal gasification plant at Wabash River in the USA in 1999. As a consequence of unstable oil prices and concerns over climate change, biomass gasification has increasingly received interest since 2001 (Basu, 2010).

Biomass gasification is a thermochemical partial oxidation process that converts biomass into gas in the presence of gasifying agents, i.e., air, steam, oxygen, carbon dioxide, or a mixture of these (Ruiz et al., 2013). The syngas product is a mixture of $\mathrm{CO}, \mathrm{H}_{2}, \mathrm{CH}_{4}$, and $\mathrm{CO}_{2}$, as well as light hydrocarbons, i.e., ethane and propane, and heavier hydrocarbons such as tars. The quality of produced gas is affected by the feedstock material, gasifying agent, design of the reactor, the presence of catalyst, and operational conditions of the reactor (Parthasarathy and Narayanan, 2014). The lower heating value (LHV) of the syngas ranges from 4 to $13 \mathrm{MJ} / \mathrm{Nm}^{3}$, as a function of feedstock, the gasification technology, and the operational conditions (Basu, 2013). The produced char is a mixture of unconverted organic fraction and ash (as a function of the treated biomass). The LHV of the char lies in the range of 25 to $30 \mathrm{MJ} / \mathrm{kg}$ depending on the amount of unconverted organic fraction (Molino et al., 2016). Biomass can be utilized as a substitute for fossil fuels in generating syngas, hydrogen, electricity, and heat, while syngas can be further processed into methanol, dimethyl ether, Fischer Tropsch (F-T) syncrude, or other chemicals (Leibbrandt et al., 2013; Petersen et al., 2015). Biomass gasification and subsequent conversions lead to several potential benefits such as sustainability, regional economic development, social and agricultural development, and reduction in GHG emissions (Demirbas and Demirbas, 2007). The gasification process still requires optimization to enhance the energy efficiency of the process by overcoming the main challenges such as tar production and moisture content of the biomass. New technologies have been developed as effective ways to utilize even toxic and wet biomass for power generation.

Environmental performance of gasification should be investigated for better design of the process. Life cycle Assessment (LCA) is a cradle-tograve approach formalized by the International Organization for Standardization (ISO, 2006), which has been regarded as a valuable environmental assessment tool for the chemical industries (Khoo et al., 2016). LCA has been widely applied to the assessment of gasification technologies (Renó et al., 2014), but the majority of the studies focused on 
the GHGs and energy balance with less attention paid to the wider range of environmental impact categories.

Recently some review papers have been published on gasification processes in general. Ahmad et al. (2016) reviewed biomass gasification considering process conditions, simulation, optimization, and economic evaluation. Heidenreich and Foscolo (2015) and Sikarwar et al. (2016) conducted a comprehensive study about gasification fundamentals, advanced process, polygeneration strategies, and new gasification concepts. Furthermore, there are some review papers about specific aspects of gasification, i.e., dual fluidized bed gasifier (Corella et al., 2007), syngas production and clean up (Göransson et al., 2011; Abdoulmoumine et al., 2015; Samiran et al., 2016), modelling (Baruah and Baruah, 2014), electricity production (Ruiz et al., 2013), and hydrogen production (Parthasarathy and Narayanan, 2014; Udomsirichakorn and Salam, 2014). While this review has focused on biomass gasification to survey the latest progress on conventional and new gasification technologies, effective parameters, different products, and applications as well as its environmental performance. Moreover, co-gasification of different feedstocks (coal and wastes) as a new technique for process improvements and waste management,is reviewed based on the recent research activities carried out.

\section{Gasification technologies}

During the gasification process, biomass undergoes a combination of drying, pyrolysis, combustion, and gasification reactions. Biomass gasification has been developed as a waste valorisation method to obtain products such as syngas, $\mathrm{H}_{2}, \mathrm{CH}_{4}$, and chemical feedstocks. The conventional gasification technologies include fixed bed (updraft and downdraft), fluidized bed, and entrained flow reactors, as demonstrated in Figure 1. A wider variety of new gasification technologies have been further developed, including plasma gasification and gasification in supercritical water of wet biomass, to convert different feedstocks to gas products (Heidenreich and Foscolo, 2015; Sikarwar et al., 2016). Besides, process integrations and combinations aim to achieve higher process efficiencies, better gas quality and purity, with lower investment costs. Therefore, the so called "emerging technologies" have received increasing attention recently, such as integration of gasification and gas cleaning technologies, or pyrolysis combined with gasification and combustion. A summary of new technologies applied for biomass gasification is represented in Table 1. $\begin{array}{lll}\text { UPDRAFT } & \text { DOWNDRAFT } & \text { FLUIDIZED BED }\end{array}$

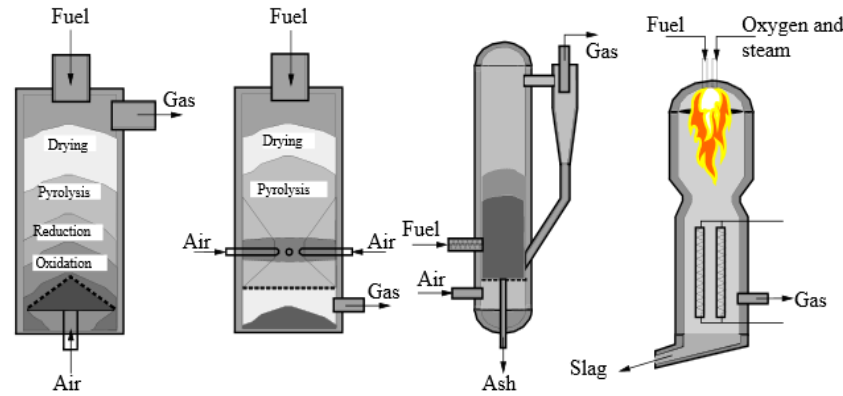

Fig.1. Conventional gasification technologies (With permission from www.biorootenergy.com).

\subsection{Fluidized bed gasifier}

Fluidized bed gasifiers are typically operated in the range of 800-1000 ${ }^{\circ} \mathrm{C}$ to avoid ash agglomeration, which is satisfactory for biomass utilization. Unlike other reactor types, a fluidized bed gasifier contains a bed of inert materials that serves as heat carrier and mixer, while the gasifying medium acts as the fluidizing gas. Typically, biomass particles are heated to bed temperature (as a result of contact with hot bed solids) and undergo rapid drying and pyrolysis, producing char and gases. The pyrolysis products break down into non-condensable gases after contact with hot solids Bubbling fluidized bed (BFD) and circulating fluidized bed (CFD) are the most conventional types of fluidized bed gasifiers.

A BFD cannot achieve complete char conversion because of the backmixing of solids. As a consequence of high degree of solid mixing, BFD gasifiers achieve temperature uniformity. An important drawback of BFD gasifiers is the slow diffusion of oxygen from the bubbles to the emulsion phase, which decreases gasification efficiency (the combustion occurs in the bubble phase) (Basu, 2013).

Table 1.

Summary of new technologies applied for biomass gasification (adopted from Heidenreich and Foscolo (2015) and Sikarwar et al. (2016)).

\begin{tabular}{|c|c|c|}
\hline Strategy employed & Advantages & Limitations \\
\hline $\begin{array}{l}\text { Combination of gasification and gas clean-up in one } \\
\text { reactor }\end{array}$ & $\begin{array}{l}\text { (i) Robust process design } \\
\text { (ii) Cost-effective }\end{array}$ & More research is needed for large-scale commercial applications \\
\hline Multi-staged gasification concept & $\begin{array}{l}\text { (i) High quality clean syngas } \\
\text { (ii) Improved process efficiency }\end{array}$ & Enhanced complexity \\
\hline $\begin{array}{l}\text { Distributed pyrolysis plants with central gasification } \\
\text { plant }\end{array}$ & $\begin{array}{l}\text { (i) Usage of distributed, low-grade biomass } \\
\text { (ii) Cost-effective transportation of char oil slurry }\end{array}$ & $\begin{array}{l}\text { Gasoline and olefins production via this process is not economically } \\
\text { viable }\end{array}$ \\
\hline Plasma gasification & $\begin{array}{l}\text { (i) Decomposition of any organic mattes } \\
\text { (ii) Treatment of hazardous waste }\end{array}$ & $\begin{array}{l}\text { (i) High investment cost } \\
\text { (ii) High power requirement } \\
\text { (iii) Low efficiency }\end{array}$ \\
\hline Supercritical water gasification (SCWG) & $\begin{array}{l}\text { (i) Liquid and biomass with high moisture content are treated } \\
\text { (ii) No pre-treatment is required }\end{array}$ & $\begin{array}{l}\text { (i) High energy requirement } \\
\text { (ii) High investment cost }\end{array}$ \\
\hline Co-generation of thermal energy with power & Enhanced process efficiency & $\begin{array}{l}\text { Only decentralized heat and power production is feasible as heat needs } \\
\text { to be produced near consumers }\end{array}$ \\
\hline Poly-generation of heat, power, and $\mathrm{H}_{2} / \mathrm{SNG}$ & $\begin{array}{l}\text { (i) Enhanced process efficiency } \\
\text { (ii) Generation of renewable } \mathrm{H}_{2} / \text { renewable fuel for transportation }\end{array}$ & $\begin{array}{l}\text { (i) Enhanced complexity in process design } \\
\text { (ii) Not economical in the absence of a natural gas distribution system }\end{array}$ \\
\hline F-T process coupled with gasification & Production of clean, carbon neutral liquid biofuels & Enhanced complexity in process design \\
\hline
\end{tabular}

Please cite this article as: Please cite this article as: Farzad S., Mandegari M.A., Görgens J.F. A critical review on biomass gasification, co-gasification, and their environmental assessments. Biofuel Research Journal 12 (2016) 483-495. DOI: 10.18331/BRJ2016.3.4.3 
In a CFD gasifier, gasification takes place in two stages; 1) combustion occurs in BFD to generate the necessary heat for gasification, and 2) pyrolysis and gasification takes place in the presence of high speed gas. The produced gas passes through a cyclone where product gas is separated from the bed materials which are re-circulated to the first stage.

Currently fluidized bed is the most promising technology in biomass gasification because of its potential to gasify a wide range of fuels (or mixture of fuels), high mixing capacity, high mass and heat transfer rate, and moreover, the possibility of using catalysts as part of the bed, which affects tar reforming (Kirnbauer et al., 2012; Gómez-Barea et al., 2013a; Udomsirichakorn et al., 2013).

\subsection{Fixed bed gasifier}

In a typical fixed bed (updraft) gasifier, fuel is fed from the top, while the pre-heated gasifying agent is fed through a grid at the bottom. As the gasifying medium enters the bottom of the bed, it meets hot ash and unconverted chars descending from the top and complete combustion takes place, producing $\mathrm{H}_{2} \mathrm{O}$ and $\mathrm{CO}_{2}$ while also raising the temperature. The released heat will heat up the upward moving gas as well as descending solids. The combustion reaction rapidly consumes most of the available oxygen; further up partial oxidation occurs, releasing $\mathrm{CO}$ and moderate amounts of heat. The mixture of $\mathrm{CO}, \mathrm{CO}_{2}$, and gasifying medium from the combustion zone, moves up into the gasification zone where the char from upper bed is gasified. The residual heat of the rising hot gas pyrolyzes the dry biomass (Basu, 2010). Updraft gasifier is not appropriate for many advanced application, due to production of 10-20 wt.\% tar in the produced gas (Ciferno and Marano, 2002).

In downdraft gasifiers, the reaction regions differ from the updraft gasifiers, as biomass fed from the top descends, while gasifying agent is fed into a lower section of the reactor. The hot gas then moves downward over the remaining hot char, where the gasification happens.

\subsection{Entrained flow gasifier}

Entrained flow gasifiers are highly efficient and useful for large scale gasification and are typically operated at high temperature $\left(1300-1500^{\circ} \mathrm{C}\right)$ and pressure values $(20-70$ bar), where the feed fine fuel $(<75 \mu \mathrm{m})$ and the gasifying agent (commonly pure oxygen) are injected in co-current (Fig. 1). The high operating temperature (well above melting point of ash) results in complete destruction of tar; therefore, these gasifiers are advantageous for biomass gasification where tar is a serious issue. To facilitate feeding into the reactor, the fuel may be mixed with water to prepare a slurry, which will lead to additional reactor volume for evaporation of the large amount of water (Basu, 2013) and 20\% higher oxygen consumption than that of dry-feed system (Higman and Van der Burgt, 2011). Utilization of biomass fine particles usually requires a torrefaction based pre-treatment (Couhert et al., 2009; Svoboda et al., 2009).

\subsection{Supercritical water gasification ( $S C W G)$}

Conversion and gasification of organic hydrocarbons in supercritical water has been fundamentally investigated since 1970s (Heidenreich and Foscolo, 2015). Water above its critical point $\left(\mathrm{T}=374.12{ }^{\circ} \mathrm{C}\right.$ and $\mathrm{P}=221.2$ bar) is termed as supercritical, where the liquid and gas phases do not exist separately, and supercritical water shows distinctive reactivity and solvency characteristics. The properties of supercritical water lie between those of the liquid and gaseous phases and a drastic reduction of density causes a significant decrease in the static relative dielectric constant (Kruse, 2008; Sikarwar et al., 2016). Water is not only a reactant involved in the reaction, but also a catalyst with significant impacts on the supercritical water gasification (SCWG) reaction process. Using supercritical water for biomass gasification is attracting growing interest for $\mathrm{H}_{2}$ and/or $\mathrm{CH}_{4}$ production and much progress has been made in the technical aspects of the processes, because it is safe, non-toxic, readily available, inexpensive, and environmentally-benign (Kruse, 2008; Guo et al., 2010; Heidenreich and Foscolo, 2015). Furthermore, SCWG is applied to wet biomass without the need for pre-drying, which is a major advantage over conventional gasification techniques. Moreover, even liquid biomass such as olive mill water can also be utilized for production of low-tar $\mathrm{H}_{2}$ gas using SCWG (Kruse, 2008; Sikarwar et al., 2016). A schematic process flow of a SCWG system is presented in Figure 2.

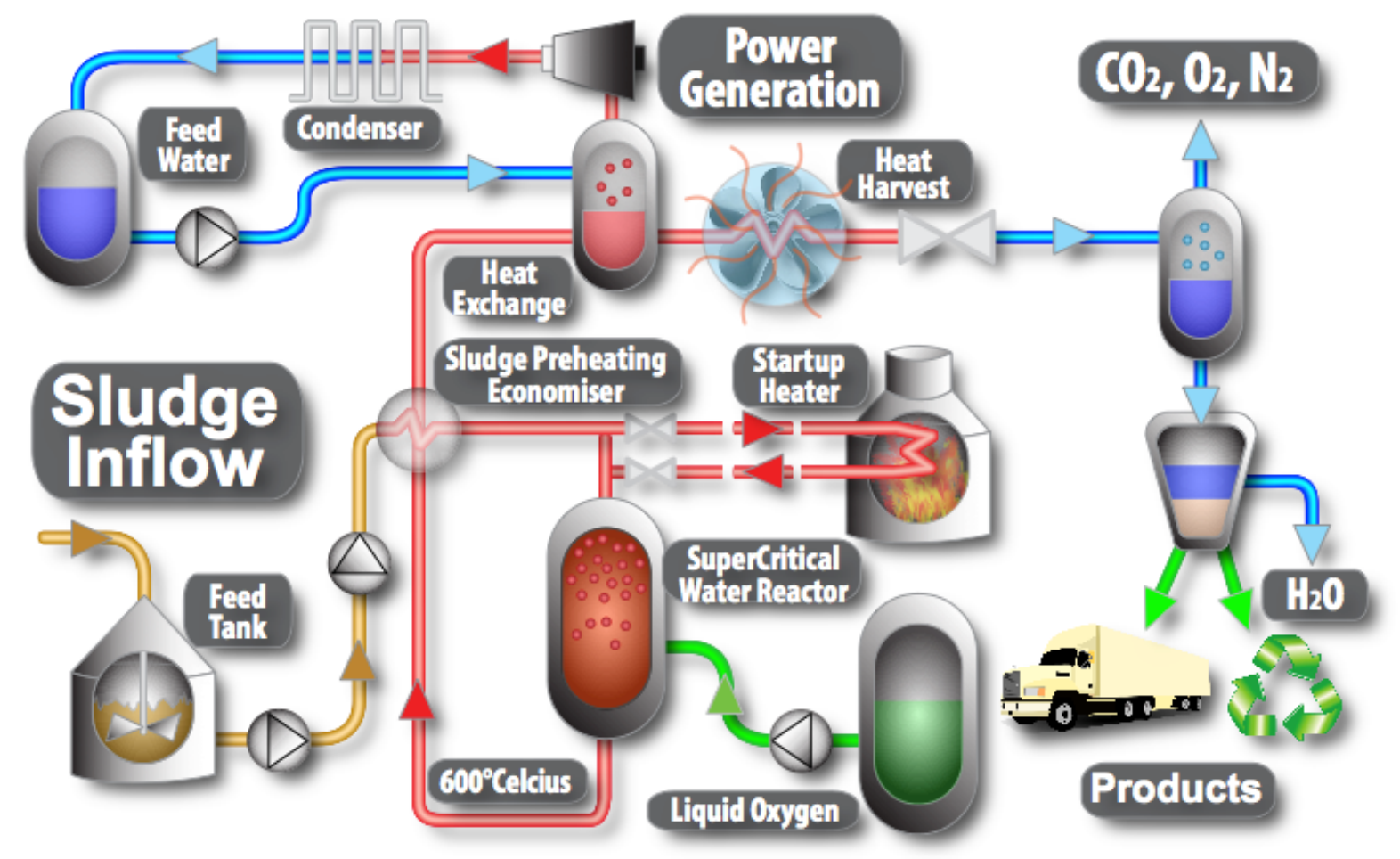

Fig.2. A schematic process flow for a SCWG system (Kamler and Andres, 2012). Copyright (2016), with permission from InTech. 
There are two approaches for biomass gasification in supercritical water, i.e., high temperature and catalytic SCWG. High-temperature SCWG employs reaction temperatures ranging from 500 to $750{ }^{\circ} \mathrm{C}$ (Matsumura et al., 2005), leading to high operating cost, which is the biggest obstacle to the development of this technology. To overcome this bottleneck, many researchers have carried out intensive research work on the catalytic supercritical water gasification (CSCWG), which employs reaction temperatures ranging from 350 to $600{ }^{\circ} \mathrm{C}$, and gasifies the feedstock with the aid of metal catalysts (Savage, 2009). At reaction temperatures below $450{ }^{\circ} \mathrm{C}$, $\mathrm{CH}_{4}$ is the main component in the produced gas, whereas at reaction temperatures above $600{ }^{\circ} \mathrm{C}$ hydrogen is dominant. At temperatures above 600 ${ }^{\circ} \mathrm{C}$, water is a strong oxidant and reacts with the carbon and releases hydrogen (Guo et al., 2010; Heidenreich and Foscolo, 2015).

SCWG can be considered as the most promising method for hydrogen production from biomass, due to the relatively high process efficiency. Generally, the calculated energy efficiencies of the different approaches and process designs of SCWG vary between $44 \%$ and $65 \%$ and the exergy efficiencies lie in the range of 41-52\% (Kruse, 2008; Lu et al., 2012). Although, SCWG has been significantly improved since its initial conception and presents a feasible technology especially for wet biomass, large-scale or commercial gasification requires further studies.

\subsection{Plasma gasification}

Plasma is defined as the fourth state of the matter, which is highly reactive due to the free electrons, ions, and neutral particles in the gas (Saber et al., 2016). To generate a plasma, a direct current (DC) discharge, alternating current (AC) discharge, radio frequency (RF) induction discharge, or microwave discharge can be used. Plasmas are classified into two categories, including "thermal or equilibrium" (atmospheric pressure) and "cold or nonequilibrium" (vacuum pressure). Thermal plasmas are produced with gases such as argon, nitrogen, hydrogen, water vapour, or a gas mixture at 470020,000 ${ }^{\circ} \mathrm{C}$ (Pfender, 1999; Gomez et al., 2009; Heidenreich and Foscolo, 2015). Thermal plasmas have some advantages, i.e., high temperature, high intensity, non-ionising radiation, and high energy density, while its drawback especially from an economic perspective, is the use of electrical power as the energy source, which leads to high construction, operation, and maintenance costs. However, a complete comparative cost evaluation often demonstrates the economic viability of plasma-based technologies (Gomez et al., 2009; Sikarwar et al., 2016). Compared with thermal plasmas, cold plasmas have lower temperatures, degrees of ionisation, and energy densities, and therefore, are applied for applications such as tar removal, local surface modification, or surface activation (Gomez et al., 2009; Du et al., 2015).

Thermal Plasma treatment has been employed for pyrolysis, gasification, and compaction of waste materials as illustrated in Figure 3 (Heberlein and Murphy, 2008). For the gasification process, plasma is applied: 1) as a heat source during gasification and 2) for tar cracking after standard gasification. Because of extremely high temperatures, thermal plasma is applicable for wet biomass, i.e., sewage sludge (Mountouris, Voutsas, and Tassios 2008) regardless of the particle size and biomass structure (Heidenreich and Foscolo, 2015).

Recently, thermal plasma gasification of biomass has been investigated by several researchers. Rutberg et al. (2011) evaluated experimentally high temperature air plasma gasification of wood for the production of syngas for combined heat and power (CHP) production. Experimental results of using AC plasma torches integrated with a thermodynamic model showed that the chemical energy in the produced syngas was $13.8-14.3 \mathrm{MJ} / \mathrm{kg}$ with a power input of 2.2-3.3 MJ/kg, while the LHV energy content of wood is $13.9 \mathrm{MJ} / \mathrm{kg}$. Motycka (2013) studied an integrated plasma gasification (biomass-to-liquids) plant to determine the production cost of F-T syncrude. The results showed that, assuming zero cost for waste refuse feedstock, the products (i.e., F-T diesel and kerosene) would be cost-competitive with similar products obtained from a petroleum process. Hlina et al. (2014) experimentally studied a plasma torch with DC electric for high temperature $\left(18000{ }^{\circ} \mathrm{C}\right)$ plasma gasification of wood, waste plastics, and pyrolysis oil. The ratio of net arc power to the mass flow rate of plasma was drastically higher than standard regime of arc, although

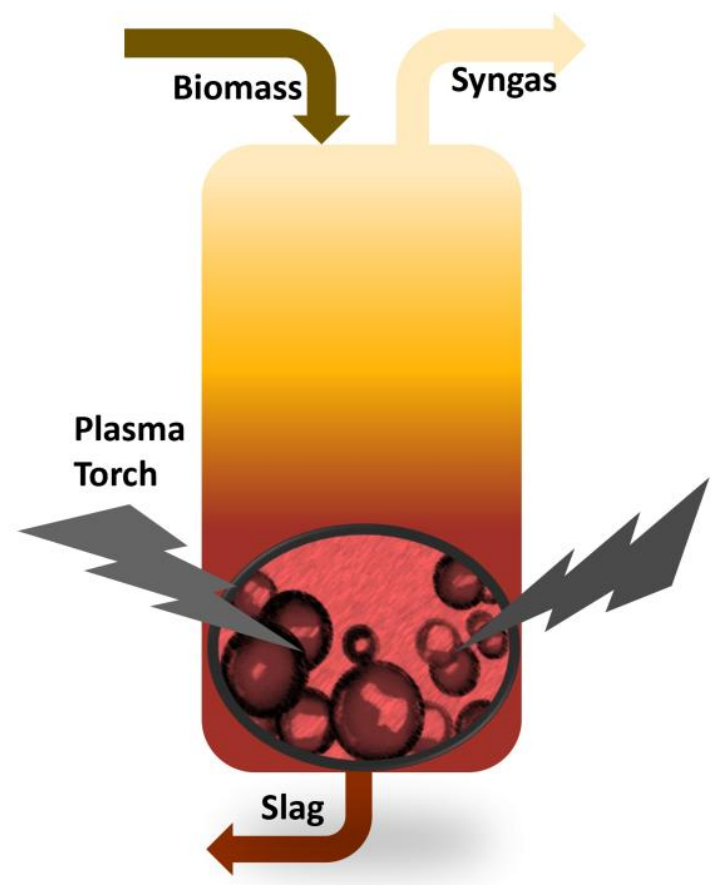

Fig.3. Schematic diagram of a plasma gasifier.

the LHV of produced syngas was also higher than normal. Furthermore, different angles of thermal plasma gasification of biomass have also been studied by previous studies (Brothier et al., 2007; Van Oost et al., 2008; Hrabovsky et al., 2009). The main reported benefits of this process are, 1) higher syngas yield with high $\mathrm{H}_{2}$ and $\mathrm{CO}$ content, 2) improved heat content, 3) low $\mathrm{CO}_{2}$ yield, and 4) low tar content (Sanlisoy and Carpinlioglu, 2016 Sikarwar et al., 2016). There are some thermal plasma facilities around the world of various capacities form $1 \mathrm{t} / \mathrm{d}$ to $300 \mathrm{t} / \mathrm{d}$, with most in the range of 5-30 t/d (Li et al., 2016) and also there are some ongoing project with higher capacities of up to $910 \mathrm{t} / \mathrm{d}$ (Fabry et al., 2013). Air Products started to build a 49 MW waste gasification plant at Teesside in England, which could produce either electricity or hydrogen from wastes as the biggest of its kind in the world (Stockford et al., 2015). However, recently (in April 2016) this project has been dropped by the company because additional design and operational challenges would require significant time and cost to rectify the current design (www.airproducts.com).

\subsection{Integration of gasification and gas cleaning}

Currently, in biomass gasification plants clean gas is produced at ambient temperature (after filtration and scrubbing), which limits its applications. Therefore, gas conditioning preceded by clean-up at elevated temperatures (i.e., hot gas clean) is necessary to ensure high efficiency in industrial applications, specifically for steam gasification. Recent developments in innovative catalysts, sorbents, and high temperature filtration media offer the opportunity to integrate biomass gasification and gas cleaning/conditioning in one reactor (Sikarwar et al., 2016). The strategy to unite biomass gasification with product gas clean-up followed by conditioning so-called UNIQUE concept gasifier, is currently in the Lab-scale testing (Heidenreich et al., 2013; Heidenreich and Foscolo, 2015).

\subsection{Integration of gasification and pyrolysis}

Gasification process of carbonaceous materials into gas comprises several overlapping process steps, such as heating and drying, pyrolysis, oxidation, and gasification. The overlapping of these process steps makes it 
impossible to control and optimize the different steps separately. Modern, advanced gasification concepts separate the pyrolysis and the gasification steps in single controlled stages to produce high gas purity with low levels of tar to improve the process efficiency as well as environmental compliance (Malkow, 2004; Heidenreich and Foscolo, 2015).

There are two different applications of this technique. 1) To combine pyrolysis and gasification directly in a two or three stage gasification process (multi-stage gasification processes) to optimize operating conditions (Ahrenfeldt et al., 2013). Several gasification processes based on the multistage gasification processes concept have been developed recently, i.e., $75 \mathrm{~kW}$ Viking gasifier developed at the Danish Technical University (Henriksen et al., 2006) and a three-stage gasifier (FLETGAS) process developed at the University of Sevilla in Spain (Gómez-Barea et al., 2013a). Staged gasification is identified as a method capable of (i) maximizing energy utilization of the fuel (maximizing char conversion), (ii) minimizing secondary treatment of the gas (by avoiding complex tar cleaning), and (iii) being applied in small (0.5-10 MWe) biomass-to-electricity gasification plants (Henriksen et al., 2006; Gómez-Barea et al., 2013a; Heidenreich and Foscolo, 2015). 2) To perform pyrolysis and gasification at different locations to concentrate biomass at decentralized small pyrolysis plants for an economical transport of the biomass pyrolysis products (liquid and solid) to a centralized large gasification plant in order to produce biofuels (Dahmen et al., 2010).

\subsection{Combination of gasification and combustion}

Combination of gasification with a combustion stage has been developed aiming at increasing the overall process efficiency, through combustion of unreacted char for additional heat production, and production of gas with a lower tar concentration (by conversion of tar through partial combustion). Biomass gasification with pure steam in a fluidized bed is connected to a fluidized-bed combustor to burn the generated char in the gasifier. This arrangement is called dual fluidized-bed biomass gasifier (DFBG) on which a significant progress in $R \& D$ and technology demonstration have made since 1975 (Corella et al., 2007; Göransson et al., 2011).

DFBGs have been employed for three purposes as illustrated in Figure $4 ; 1)$ to supply heat for gasification (the common), 2) to supply oxygen (the chemical loop combustion (CLC) process), and 3) to capture $\mathrm{CO}_{2}$ (the absorption enhanced reforming (AER) process) (Göransson et al., 2011 Shrestha et al., 2016). Apart from DFBG, partial combustion has also attracted an increasing deal of interest in recent years as a method to achieve thermal tar conversion. Air/fuel ratio, hydrogen concentration, methane concentration, temperature, and free radicals produced during the combustion, influence the cracking or polymerization reactions of the tar components (Houben et al., 2005; Anis and Zainal, 2011; Gómez-Barea, et al., 2013b).

\section{Co-Gasification}

Co-asification is defined as gasification of a mixture of waste/biomass and oal which offers several opportunities, especially to utility companies and customers, to protect the environment by reducing GHG emissions from existing process equipment. In recent years, co-gasification of biomass and coal has been broadly investigated by researchers (Collot et al., 1999; Aigner et al., 2011; Taba et al., 2012), because it creates opportunities in industries such as forestry, agriculture, and food processing to manage large quantities of combustible agricultural and wood wastes. In addition, the cost of adapting an existing coal power plant to co-fire biomass is significantly lower than the cost of building new systems dedicated only to biomass power. The biomass rate in the range of 3-5\% on energy basis

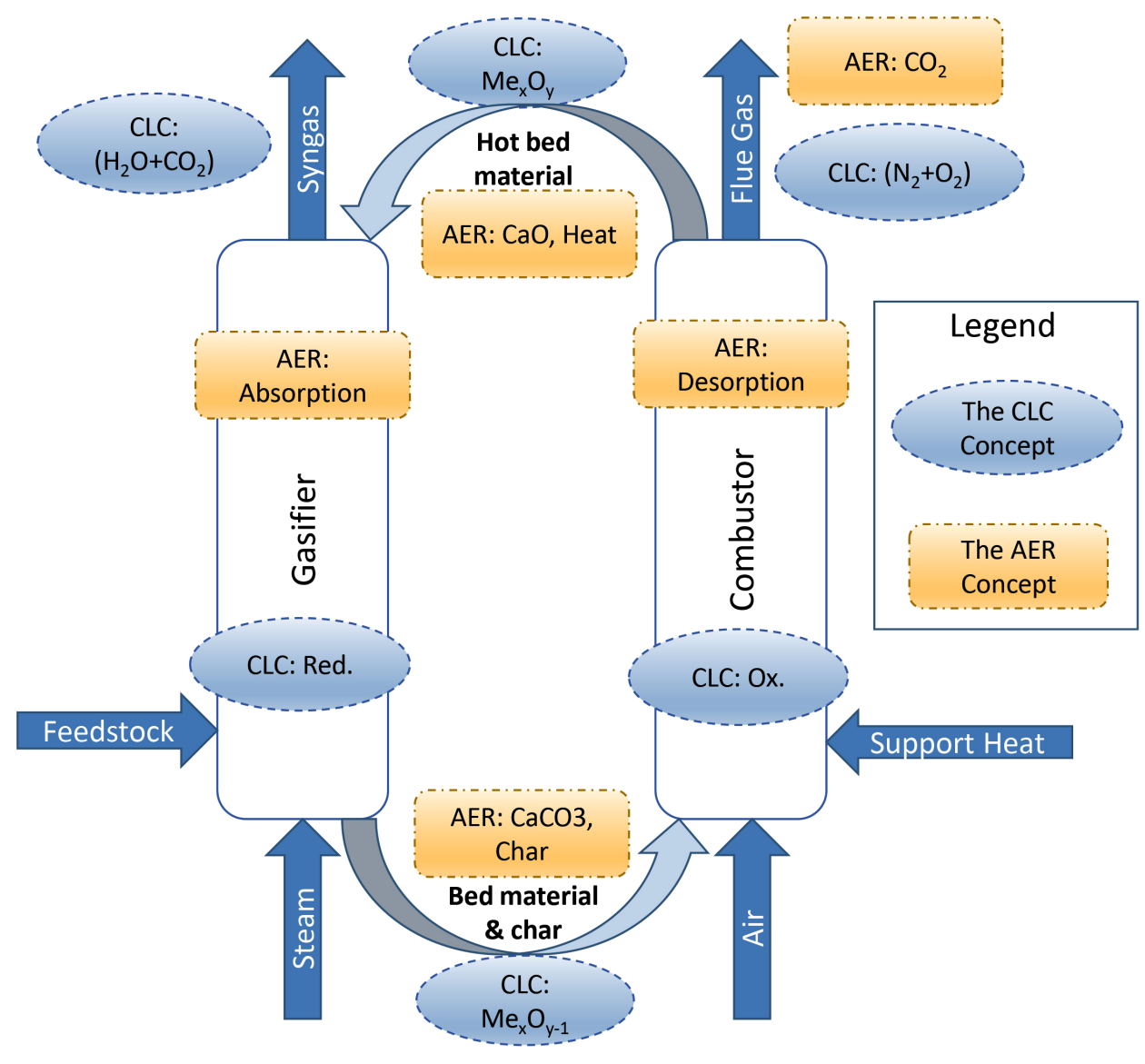

Fig.4. A Schematic view of dual fluidized-bed biomass gasifiers (DFBG) (adopted from Göransson et al., 2011). 
Table 2.

Summary of research works on co-gasification of different feedstocks.

\begin{tabular}{|c|c|c|c|c|}
\hline Feedstock & Gasifier type & Gasification conditions & Concise results & Reference \\
\hline $\begin{array}{l}\text { - Petroleum coke } \\
\text { - Pine pellets }\end{array}$ & 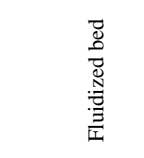 & $\begin{array}{l}\text { (i) Gasification agent: steam } \\
\text { (ii) Biomass ratio: } 50 \%, 80 \% \text {, and } 100 \% \\
\text { (iii)Temperature: } 800 \text { and } 900{ }^{\circ} \mathrm{C} \text {, } \\
\text { (iv) Total gasification time: } 2.5-3 \mathrm{~h}\end{array}$ & $\begin{array}{l}\text { (i) The activation energy decreased with increasing } \\
\text { biomass ratio. } \\
\text { (ii) Higher gasification temperature and oxygen } \\
\text { concentration led to higher petcoke conversion and } \\
\text { decreased tar concentration. }\end{array}$ & Nemanova et al. (2014) \\
\hline $\begin{array}{l}\text { - Shinhwa coal } \\
\text { - } \quad \text { Pine sawdust }\end{array}$ & 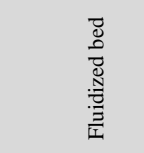 & $\begin{array}{l}\text { (i) Gasification agent: } \mathrm{CO}_{2} 40 \% \text {, and } \mathrm{N}_{2} 60 \% \\
\text { (ii) Biomass ratio: } 0 \%, 25 \%, 75 \% \text {, and } 100 \% \\
\text { (iii) Temperature: } 900,1000 \text {, and } 1100{ }^{\circ} \mathrm{C} \\
\text { (iv) The ratio of fuel/ } \mathrm{CO}_{2}: 0.20,0.21,0.21 \text {, and } \\
0.23\end{array}$ & $\begin{array}{l}\text { (i) The reactivity of char was improved with an } \\
\text { increasing amount of biomass. } \\
\text { (ii) The random pore model (RPM) could be used to } \\
\text { interpret the carbon conversion data. }\end{array}$ & Jeong et al. (2014) \\
\hline
\end{tabular}

$\begin{array}{lll} & \text { (i) Gasification agent: steam } \\ \text { - Plastics (PE) } & \text { (ii) Biomass ratio: } 0 \%, 25 \%, 75 \% \text {, and } 100 \% \\ & \text { (iii) Temperature: } 850{ }^{\circ} \mathrm{C} \\ & \text { (iv) Steam-to-carbon mass ratio (SCR): } 2.3 \\ & \text { (v) Heterogeneous catalyst: olivine }\end{array}$

(i) Co-gasification led to successful thermochemical conversion of plastics as opposed to mono-gasification (ii) Elevating the plastics content in feed resulted in increased fractions of ethane and ethylene and decreased $\mathrm{CO}_{2}$

\begin{tabular}{|c|c|c|c|c|}
\hline $\begin{array}{l}\text { - } \quad \text { Hard coal } \\
\text { Energy crops }\end{array}$ & 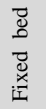 & $\begin{array}{l}\text { (i) Gasification agent: steam } \\
\text { (ii) Biomass ratio: } 0 \%-100 \% \text { with } 20 \% \text { intervals } \\
\text { (iii) Temperature: } 700,800 \text {, and } 900{ }^{\circ} \mathrm{C}\end{array}$ & $\begin{array}{l}\text { (i) The reactivity of char increased with temperature. } \\
\text { (ii) The reactivity for chars of fuel blends was higher } \\
\text { than biomass chars irrespective of the temperature. }\end{array}$ & $\begin{array}{l}\text { Howaniec and } \\
\text { Smoliński (2013) }\end{array}$ \\
\hline
\end{tabular}

\begin{tabular}{lll}
\hline & (i) Gasification agent: $\mathrm{CO}_{2}$ \\
- Bituminous coals & (ii) Biomass ratio: $0 \%-30 \%$ \\
- Cedar bark. & (iii) Temperature: 1200 and $1300{ }^{\circ} \mathrm{C}$ \\
& (iv) Pressure: $0.5 \mathrm{MPa}$ \\
& (v) The ratio of fuel/ $/ \mathrm{CO}_{2}: 0.20,0.21,0.21$, and \\
& 0.23
\end{tabular}

(i) The reactivity of mixture was higher than single coal at $1200^{\circ} \mathrm{C}$.

(ii) The reactivity was almost the same at $1400{ }^{\circ} \mathrm{C}$. (iii) Distinguished synergy to improve the gasification reactivity was not observed.

\begin{tabular}{|c|c|c|c|c|}
\hline $\begin{array}{ll}\text { - } & \text { Pine sawdust } \\
\text { - } & \text { Plastic } \\
\text { - } & \text { Coal }\end{array}$ & 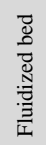 & $\begin{array}{l}\text { (i) Gasification agent: air; ER: } 0.3-0.46 \\
\text { (ii) Feed blend: } 60 \% \text { coal, } 20 \% \text { pine, and } 20 \% \\
\text { plastic } \\
\text { (iii) Temperature: } 750-880{ }^{\circ} \mathrm{C} \\
\text { (iv) Catalyst: dolomite }\end{array}$ & $\begin{array}{l}\text { (i) The optimal condition was: temperature, } 850{ }^{\circ} \mathrm{C} \\
\text { and ER: } 0.36 \text { equivalent ratio. } \\
\text { (ii) Resulted gas contained medium hydrogen content } \\
\text { (up to } 15 \% \text { dry basis) and low tar content. }\end{array}$ & Aznar et al. (2006) \\
\hline
\end{tabular}

\section{(i) $\mathrm{CO}$ increased}

$\begin{array}{lll}\text { - Pine chips } & \text { (i) Gasification agent: air-steam } \\ \text { - Black coal } & \text { (ii) Biomass ratio: } 0 \%, 25 \%, 40 \% \text {, and } 100 \% \\ \text { - Sabero coal } & \text { (iii) Temperature: } 840-910^{\circ} \mathrm{C}\end{array}$

(ii) $\mathrm{H}_{2}$ first increased up to $25 \%$ of biomass and then decreased.

(iii) Overall thermal efficiency increased ( $40 \%$ to $68 \%)$.

(iv) Carbon conversion efficiency increased (63\% to

$83.4 \%)$.

can be directly co-fired. However, this rate may rise to $20 \%$ when cyclone boilers are used (Savolainen, 2003; Agbor et al., 2014).

The produced syngas of co-gasification is hydrogen-rich and contains $\mathrm{CH}_{4}$, which can be used for power plants. During the co-gasification process, the volatiles readily decompose and form free radicals which react with the organic matters of the coal, thus, the conversion rate increases while the $\mathrm{CO}_{2}, \mathrm{SO}_{2}$ and $\mathrm{NO}_{\mathrm{x}}$ emissions reduce.

Since different kinds of coal and biomass have different properties, it is possible to vary the contents and yield of gaseous products from the cogasification process by changing the amounts and properties of the fuel mixture and temperature (Taba et al., 2012; Emami-Taba et al., 2013). The results of an experimental study of coal and biomass mixture $(0-100 \%)$ showed linear relationship with changing fuel ratios and gas components, while high wood ratios led to a gas, more suitable for F-T synthesis and synthetic natural gas (SNG) production due to a higher $\mathrm{H}_{2} / \mathrm{CO}$ ratio (Aigner et al., 2011). Pinto et al. (2009 and 2010) have evaluated the gas produced by co-gasification of coal and wastes blends (olive oil bagasse, pine, and polyethylene) in two catalytic fixed bed (dolomite and Ni based catalysts) reactors. Based on their results, it was possible to substitute one type of waste by another, without great changes to the gasifier but both the released tar and hydrocarbons were different. The presence of wastes in the feedstock led to higher concentrations of hydrocarbons and tar in the gas obtained.

Direct co-firing of biomass can result in several problems, due to high alkaline and chlorine contents of biomass. Main reported problems are corrosion, slagging, fouling in the boiler as well as heat exchanger and piping, poisoning of catalysts, and performance problems in electrostatic precipitators (Heidenreich and Foscolo, 2015). To overcome these problems, indirect and parallel co-firing have been introduced (Sami et al., 2001; Agbor et al., 2014), but the production cost of the plant (CAPEX and OPEX) is higher than the direct co-firing. In addition to biomass and coal co-gasification, co-gasification of biomass with plastic wastes (Pinto et al., 2002), petroleum coke (Nemanova et al., 2014), and tire (Lahijani et al., 2013) have also been studied. A summary of co-gasification studies have been presented in Table 2. 


\section{Products of biomass gasification}

\subsection{Syngas production}

Syngas is known as an important source for production of valuable chemicals, i.e., diesel or gasoline (via F-T synthesis), hydrogen (produced in refineries), fertilizers (through ammonia), and methanol (Diederichs et al., 2016; Leibbrandt et al., 2011). The syngas from a typical gasifier contains $\mathrm{H}_{2}$, $\mathrm{CO}, \mathrm{CO}_{2}, \mathrm{CH}_{4}, \mathrm{H}_{2} \mathrm{O}$, trace amount of higher hydrocarbons, possible inert gases present in the gasification agent, and various contaminants (Göransson et al., 2011). The composition of syngas is dependent on the gasifying medium and utilization of steam or oxygen (the most appropriate gasifying medium for syngas production) instead of air will lead to lower nitrogen content in the product gas (Yin et al., 2004). In low temperature gasification, heavier hydrocarbons are also produced along with $\mathrm{CO}$ and $\mathrm{H}_{2}$, which are further cracked and separated from the products. For maximum syngas production with minimum tar formation, the reaction temperature should be increased (because of endothermic gasification reactions), while the volatile residence time should be extended (to increase tar cracking). In terms of biomass gasification, a high alkali content (influencing the softening temperature of the generated ash and consequently agglomeration problems) limits the maximum allowable gasification temperature (Corella et al., 2008). Since high ash content causes slagging, usually biomass with low ash content should be utilized for syngas production (Sikarwar et al., 2016). Considering the requirements of the downstream process, gasification is often followed by the shift reaction to adjust $\mathrm{H}_{2} / \mathrm{CO}$ ratio.

\subsection{Hydrogen enriched gas production}

Hydrogen plays a very important role in the development of hydrogen economy and many studies are conducted in this regard ( Lu et al., 2012; Ni et al., 2006; Guo et al., 2010; Sekoai and Daramola, 2015). Hydrogen is mostly produced from fossil fuels, i.e., natural gas, coal, and oil, while only $4 \%$ of hydrogen is produced from renewable resources (Parthasarathy and Narayanan, 2014). Amongst renewable sources of hydrogen (biomass, solar, and wind) only biomass can directly generate hydrogen, while other sources have to undertake electrolysis of water. A lot of initiatives have been undertaken to promote hydrogen production from biomass, i.e., the international energy agency's (IEA) program launched the project of $\mathrm{H}_{2}$ production and utilization from carbon-coating materials. Hydrogen can be produced from biomass through thermochemical (pyrolysis, gasification, steam gasification, and SCWG) or biochemical routes, while thermochemical pathways deliver higher efficiency at a lower cost (Balat and Kirtay, 2010; Sekoai and Daramola, 2015). Although biological pathways are less energy-intensive and more environmentally friendly, their low rate of hydrogen production is the major challenge. Therefore, biological methods have not been considered in most scenarios of future hydrogen economy (Ni et al., 2006).

During the gasification process, water-gas shift reaction (WGSR) converts the reformed gas into hydrogen, while pressure swing adsorption (PSA) process is used for product purification. Steam gasification technology is a wellestablished method of producing renewable $\mathrm{H}_{2}$ with highest yield of $\mathrm{H}_{2}$ from biomass and minimal environmental impacts (Parthasarathy and Narayanan, 2014). It has been reported that steam gasification will increase the yield by three folds, compared with air gasification (Nipattummakul et al., 2010), because WGSR (which is necessary for $\mathrm{H}_{2}$ production) will be enhanced (Wei et al., 2007). Utilisation of pure steam is proven to be more economical than the other conventional gasifying agents (Franco et al., 2003). The evolution of $\mathrm{H}_{2}$ will be increased at higher temperatures, due to significantly faster gasification reaction at temperatures above $800{ }^{\circ} \mathrm{C}$ (Nipattummakul et al., 2010).

The SCWG is a method for hydrogen production that is particularly appropriate for high moisture content biomass, but it is more expensive than the current price of $\mathrm{H}_{2}$ from steam methane reforming (Matsumura et al., 2006). Although this method is believed to deliver higher efficiencies, it is still under development and requires more research to make it proven.

An important factor in maximizing $\mathrm{H}_{2}$ production is known to be utilisation of catalyst in the gasification process, where nickel-based catalysts have been efficient in tar reduction and $\mathrm{H}_{2}$ production (Sutton et al., 2001; Wu et al. 2011; Ruoppolo et al., 2012).

A higher steam-to-biomass (S/B) ratio leads to higher steam partial pressure and enhances the shift reaction to $\mathrm{H}_{2}$ production (Göransson et al., 2011). But, increasing the S/B ratio beyond the threshold limit, produces excess steam in the syngas which will lead to efficiency reduction (Sharma and Sheth, 2016). Production of hydrogen from biomass gasification is facing problems due to presence of tar in the gas product and low energy content (by volume) of hydrogen (Ahmed et al., 2012).

\subsection{Electricity production}

Generating electricity is one potential application of biomass gasification that has been widely applied worldwide. Syngas carries particulate matters and light hydrocarbons which should be cleaned up before its combustion for electricity generation. The syngas cleaning (which is the less developed aspect) is a critical and costly step, which caused closures of some electricity production plants due to technical issues and ash problems (Negro et al., 2008; Ruiz et al., 2013).

\subsection{Biomass gasification co-generation}

Co-generation is an approach to improve the economic and sustainability aspects of the biomass gasification. Co-generation refers to the combined production of two products or more (poly-generation) to maximize the transformation efficiency of the energy and material of the feedstock into products. As an additional advantage, co-generation offers flexibility regarding the changes of market demands. CHP production is a classic example for a co-generation process (Ahrenfeldt et al., 2013; Heidenreich and Foscolo, 2015).

CHP production units can provide heat and power to industrial, commercial, and residential buildings. CHP by biomass combustion is prevalent, however, gasification is better in terms of electrical efficiency and the acceptable range of biomass qualities (Berggren et al., 2008). The combination of biomass gasification and a gas engine for CHP is a logical choice in the small-scale range and with a biomass to power efficiency potential of $35-40 \%$, which is high compared with conventional technology (Ahrenfeldt et al., 2013; Kumar et al., 2015). In order to reduce the technical problems, a small size (1-10 MW) of the plant could be attractive (Ahrenfeldt et al., 2013; Asadullah, 2014). Many researchers have investigated the CHP co-generation strategy to enhance electricity production. Some researchers have coupled an Organic Rankine cycle (ORC), which additionally transforms $10-15 \%$ of heat into electricity, and improved biomass power efficiency (Heidenreich and Foscolo, 2015; Sikarwar et al., 2016). Another approach is the integrated gasification combined cycle (IGCC) process, where a gas turbine and a steam turbine are combined to generate electricity. Since small steam turbines have a low electrical efficiency, an IGCC process is only interesting for larger scale applications (Corti and Lombardi, 2004; Sikarwar et al., 2016).

By using selective syngas conversion reactions with different catalysts various organic products can be manufactured, e.g., methanol, dimethylether (DME), olefins, methane, hydrogen, F-T diesel, etc. (Henrich et al., 2009).

Newer processes compared with CHP co-generation; aim to combine SNG or hydrogen and heat production, or biofuels, heat, and power production. SNG from biomass is considered as a renewable clean fuel substitute for fossil fuels in heating, CHP, and transportation systems. During the last 10 years, the production of SNG from biomass gasification syngas has gained increasing interest and has been investigated by some research groups such as the Energy Research Center of the Netherlands (ECN), the Paul-Scherrer Institute (PSI) in Switzerland, and Güssing in Germany (Dahmen et al., 2010; Heidenreich and Foscolo, 2015). Sweden is a pioneer country for bio-SNG production and GoBiGas project in Göteborg as a commercial plant with $20 \mathrm{MW}$ has been fully operational since 2014 while the second phase of this plant with a capacity of $80 \mathrm{MW}$ is currently under construction (Ahrenfeldt et al., 2013; Zinn and Thunman, 2016). 


\section{Life cycle assessment of biomass gasification}

One of the main drivers for the intensified utilization of biomass to produce energy and other materials is its potential to reduce the environmental impacts of fossil fuels utilization. Various methodologies have been applied for examination of environmental impacts, while LCA is one of the most widely used methods. LCA first received attention in 1960s, but only in 1997 International Organization for Standardization (ISO) developed the LCA standard (Kalinci et al., 2012). Literature surveys have suggested that although there are various studies on energy analysis of biomass gasification, LCA of these systems has been rarely studied. Most of the research works have considered GHG emissions (Boerrigter and Rauch, 2006; Moreno and Dufour, 2013), but few have studied complete environmental impacts. A summary of environmental assessments on gasification, based on feedstock, technology, and product have been tabulated in Table 3 .

Different studies have focused on GHG emissions of different plant sizes or feedstock types for electricity or heat generation from biomass. The GHG emissions of electricity production through biomass co-firing in coal plants have been analysed by different research groups (Zhang et al., 2009; Froese et al., 2010). Different sizes of co-generation plants have also been investigated by Upadhyay et al. (2012) in Canada.

Environmental studies on $\mathrm{H}_{2}$ production have focused on different

Table 3.

Summary of LCA studies on biomass gasification.

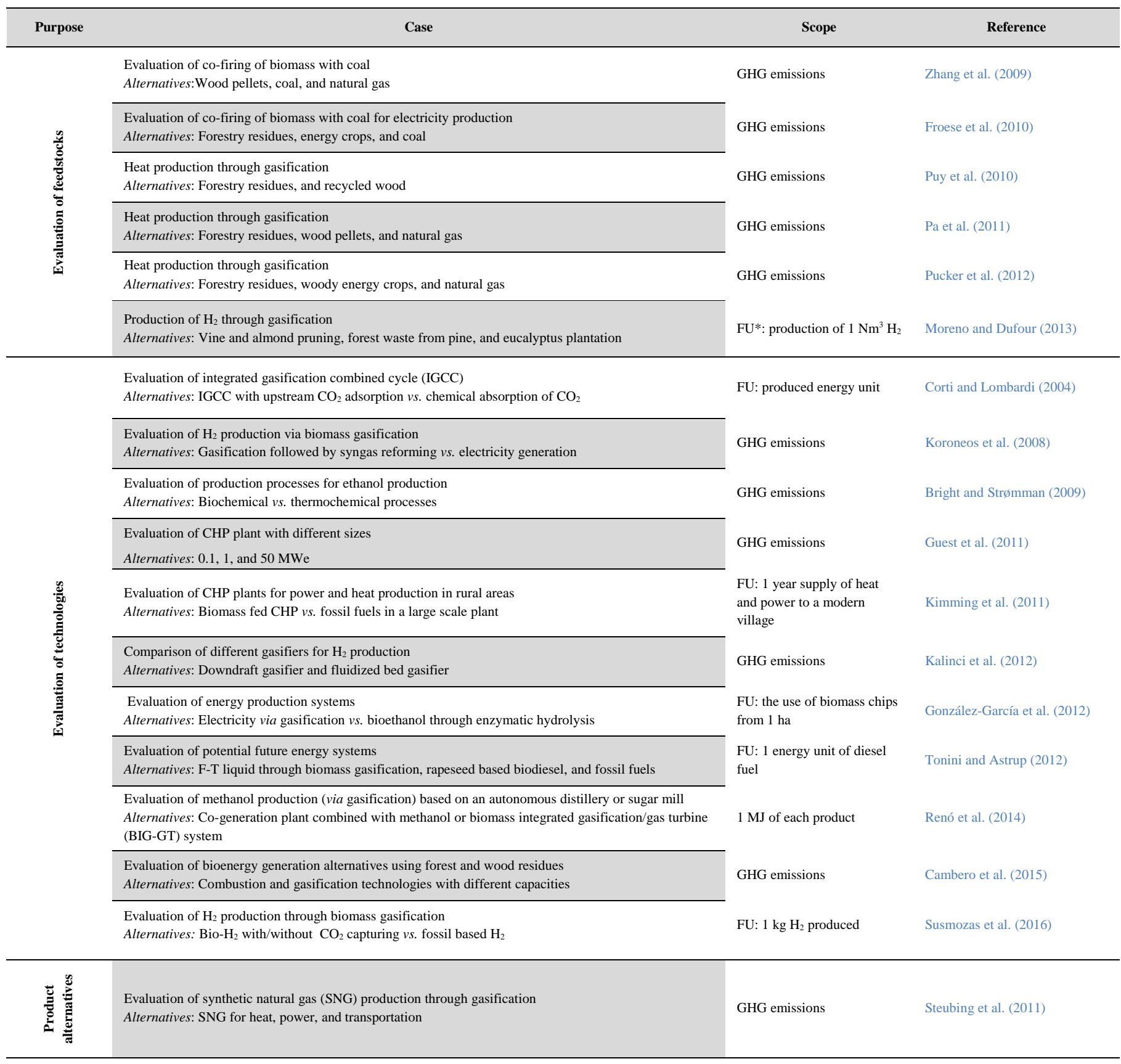

* FU; Functional unit of LCA study 
technologies or different feedstock sources, separately. The environmental feasibility of $\mathrm{H}_{2}$ production through biomass gasification - by investigating several feedstocks - have been studied by Moreno and Dufour (2013). Their results indicated that main factors contributing to environmental performance of biomass gasification are yield to gas and requirements of fertilizers and pesticides in biomass growth (Moreno and Dufour, 2013). Their study also showed that recovery and use of valuable products such as non-converted methane improved the environmental performance of the process. Koroneos et al. (2008) studied the environmental aspects of $\mathrm{H}_{2}$ production via different renewable sources including biomass.

A comparative LCA study of two different gasification systems (downdraft gasifier and $\mathrm{CFB}$ gasifier) for $\mathrm{H}_{2}$ production proved that downdraft gasifier delivered better environmental performance over CFB gasifier (Kalinci et al., 2012). According to the LCA study of hydrogen production by Susmozas et al. (2016), direct emission to air, external electricity production, and biomass production are the key processes contributing to environmental impacts, while bio-hydrogen production with $\mathrm{CO}_{2}$ capture delivers superior environmental performance over conventional processes.

Since biomass gasification is an economically interesting solution to produce syngas with low/medium heating value which can be transformed into electricity (González-García et al., 2012), LCA has been applied by different researchers to assess the environmental impacts of electricity generation from biomass. Environmental performance of different electricity production technologies has also been studied. Study of environmental impacts of electricity production in Denmark showed that GHG emissions can be significantly reduced (from 68 to $17 \mathrm{Gg} \mathrm{CO}_{2}$-eq/PJ) by increased utilization of residual biomass (Tonini and Astrup, 2012). A comparative study revealed that electricity production from biomass delivered significantly lower $\mathrm{CO}_{2}$

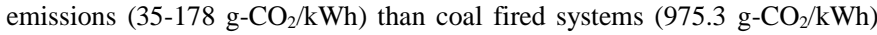
(Varun et al., 2009).

Environmental effects of electricity production via co-gasification of coal and biomass resulted in much lower $\mathrm{CO}_{2}$ emission, in comparison with coal gasification (Hartmann and Kaltschmitt, 1999). IGCC of biomass - with upstream $\mathrm{CO}_{2}$ adsorption - has been compared with IGCC with chemical absorption of $\mathrm{CO}_{2}$ at the stack (Corti and Lombardi, 2004). The environmental performance of an IGCC with $\mathrm{CO}_{2}$ removal - through chemical absorption has also been studied on the basis of Eco-indicator 95 methodology and compared with similar energy conversion cycle fed by coal (Carpentieri et al., 2005). In a different investigation, the environmental assessment of three different CHP systems revealed that biomass-based scenarios reduced GHG emissions considerably, but delivered higher acidification impacts compared with fossil fuel-based scenarios (Kimming et al., 2011).

Life cycle analyses of GHG emissions of bioenergy systems including combustion and gasification technologies - with different capacities - in British Columbia were investigated by Cambero et al. (2015). Their results implied that in the community where all energy needs were satisfied with fossil fuels and biomass residues were disposed of by burning, net reduction of up to 40,909 t of $\mathrm{CO}_{2}$ equivalent $\mathrm{GHG}$ emissions could be achieved. However, in the community where the current energy was mostly supplied from other renewable sources, the net achievable GHG emissions reduction was significantly lower.

\section{Concluding remarks and future prospects}

Gasification of biomass is a promising technology which converts biomass to valuable products such as $\mathrm{H}_{2}$, electricity, and syngas (can be further processed to methanol, F-T syncrude, etc.). Gasification products are a function of applied technology, temperature, pressure, gasifying agent, and the fuel/gasifying medium ratio. More new technologies such as plasma gasification and SCWG deliver higher efficiencies and lower tar productions, while are capable of treating wider ranges of biomass and are mostly appropriate for wet biomass. Various co-generation approaches to produce heat and power along with other products, demonstrate more economically-viable scenarios. Furthermore, co-gasification of biomass and coal can be applied to reduce the consumption of fossil fuels and increase utilization of waste/biomass, leading to less unpleasant products, (i.e., tar), higher carbon conversion, and higher gas yield than coal/biomass gasification. Environmental studies of biomass gasification have proven the potential of reducing GHG emissions, but there is a need for more comprehensive LCAs, taking into account the whole environmental impact categories. Co-gasification and co- generation can be promising future renewable energy scenarios, which require further studies specifically by considering their environmental effects (LCA analysis).

\section{References}

[1] Abdoulmoumine, N., Adhikari, S., Kulkarni, A., Chattanathan, S. 2015. A review on biomass gasification syngas cleanup. Appl. Energy. 155, 294-307.

[2] Agbor, E., Zhang, X., Kumar, A., 2014. A review of biomass co-firing in North America. Renew. Sust. Energy Rev. 40, 930-943.

[3] Ahmad, A.A., Zawawi, N.A., Kasim, F.H., Inayat, A., Khasri, A. 2016. Assessing the gasification performance of biomass: a review on biomass gasification process conditions, optimization and economic evaluation. Renew. Sust. Energy Rev. 53, 1333-1347.

[4] Ahmed, T.Y., Ahmad, M.M., Yusup, S., Inayat, A., Khan, Z., 2012. Mathematical and computational approaches for design of biomass gasification for hydrogen production: a review. Renew. Sust. Energy Rev. 16(4), 2304-2315.

[5] Ahrenfeldt, J., Thomsen, T.P., Henriksen, U., Clausen, L.R., 2013. Biomass gasification cogeneration: a review of state of the art technology and near future perspectives. Appl. Therm. Eng. 50(2), 1407-1417.

[6] Aigner, I., Pfeifer, C., Hofbauer, H., 2011. Co-gasification of coal and wood in a dual fluidized bed gasifier. Fuel. 90(7), 2404-2412.

[7] Akia, M., Yazdani, F., Motaee, E., Han, D., Arandiyan, H., 2014. A review on conversion of biomass to biofuel by nanocatalysts. Biofuel Res. J. 1(1), 16-25

[8] Anis, S., Zainal, Z.A., 2011. Tar reduction in biomass producer gas via mechanical, catalytic and thermal methods: a review. Renew. Sust. Energy Rev. 15(5), 2355-2377

[9] Asadullah, M., 2014. Biomass gasification gas cleaning for downstream applications: a comparative critical review. Renew. Sust. Energy Rev. 40, 118-132.

[10] Aznar, M.P., Caballero, M.A., Sancho, J.A., Francés, E., 2006. Plastic waste elimination by co-gasification with coal and biomass in fluidized bed with air in pilot plant. Fuel Process. Technol. 87(5), 409420.

[11] Balat, H., Kirtay, E., 2010. Hydrogen from biomass-present scenario and future prospects. Int. J. Hydrogen Energy. 35(14), 7416-7426.

[12] Baruah, D., Baruah, D.C., 2014. Modeling of biomass gasification: a review. Renew. Sust. Energy Rev. 39, 806-815.

[13] Basu, P., 2010. Biomass gasification and pyrolysis: practical design and theory. Academic press

[14] Bauen, A., Berndes, G., Junginger, M., Londo, M., Vuille, F., Ball, R., Bole, T., Chudziak, C., Faaij, A., Mozaffarian, H., 2009. Bioenergy-a sustainable and reliable energy source. a review of status and prospects. bioenergy: a sustainable and reliable energy source. a review of status and prospects. IEA Bioenergy.

[15] Berggren, M., Ljunggren, E., Johnsson, F., 2008. Biomass co-firing potentials for electricity generation in poland-matching supply and co-firing opportunities. Biomass Bioenergy. 32(9), 865-879.

[16] Bhat, I.K., Prakash, R., 2009. LCA of renewable energy for electricity generation systems-a review. Renew. Sust. Energy Rev. 13(5), 1067. 1073

[17] Knoef, H.A.M., 2005. Handbook biomass gasification. Meppel, The Nederlands: BTG Biomass Technology Group B.V

[18] Bright, R.M., Strømman, A.H., 2009. Life cycle assessment of second generation bioethanols produced from Scandinavian boreal forest resources. J. Ind. Ecol. 13(4), 514-531.

[19] Brothier, M., Gramondi, P., Poletiko, C., Michon, U., Labrot, M. Hacala. A., 2007. Biofuel and hydrogen production from biomass gasification by use of thermal plasma. High Temperature Material Processes: An International Quarterly of High-Technology Plasma Processes. 11, 2

[20] Cambero, C., Alexandre, H.M., Sowlati, T., 2015. Life cycle greenhouse gas analysis of bioenergy generation alternatives using forest and wood residues in remote locations: a case study in British Columbia, Canada. Resour. Conserv. Recycl. 105, 59- 
[21] Carpentieri, M., Corti, A., Lombardi, L., 2005. Life cycle assessment (LCA) of an integrated biomass gasification combined cycle (IBGCC) with $\mathrm{CO}_{2}$ removal. Energy Convers. Manage. 46(11-12), 1790-1808.

[22] Ciferno, J.P., Marano, J.J., 2002. Benchmarking biomass gasification technologies for fuels, chemicals and hydrogen production. US department of energy. US Department of Energy. National Energy Technology Laboratory.

[23] Collot, A.G., Zhuo, Y., Dugwell, D.R., Kandiyoti, R., 1999. Co-pyrolysis and co-gasification of coal and biomass in bench-scale fixed-bed and fluidised bed reactors. Fuel. 78(6), 667-679.

[24] Corella, J., Toledo, J.M., Molina, G., 2008. Biomass gasification with pure steam in fluidised bed: 12 variables that affect the effectiveness of the biomass gasifier. Int. J. Oil Gas Coal Technol. 1(1-2), 194-207.

[25] Corella, J., Toledo, J.M., Molina, G., 2007. A review on dual fluidizedbed biomass gasifiers. Ind. Eng. Chem. Res. 46(21), 6831-6839.

[26] Corti, A., Lombardi, L., 2004. Biomass integrated gasification combined cycle with reduced $\mathrm{CO}_{2}$ emissions: performance analysis and life cycle assessment (LCA). Energy. 29(12-15), 2109-2124.

[27] Couhert, C., Salvador, S., Commandré, J.M., 2009. Impact of torrefaction on syngas production from wood. Fuel. 88(11), 2286-2290.

[28] Dahmen, N., Henrich, E., Kruse, A., Raffelt, K., 2010. Biomass liquefaction and gasification. biomass to biofuels: strategies for global industries. Wiley Blackwell Science, UK.

[29] Demirbas, A.H., Demirbas, I., 2007. Importance of rural bioenergy for developing countries. Energy Convers. Manage. 48(8), 2386-2398.

[30] Diederichs, G.W., Mandegari, M.A., Farzad, S., Görgens, J.F., 2016. Techno-economic comparison of biojet fuel production from lignocellulose, vegetable oil and sugar cane juice. Bioresour. Technol. 216, 331-339.

[31] Din, Z.U., Zainal, Z.A., 2016. Biomass integrated gasification-SOFC systems: technology overview. Renew. Sust. Energy Rev. 53 , 13561376

[32] Du, C., Wu, J., Ma, D., Liu, Y., Qiu, P., Qiu, R., Liao, S., Gao, D., 2015. Gasification of corn cob using non-thermal arc plasma. Int. J. Hydrogen Energy. 40(37), 12634-12649.

[33] Emami-Taba, L., Irfan, M.F., Daud, W.M.A.W., Chakrabarti, M.H., 2013. Fuel blending effects on the co-gasification of coal and biomass-a review. Biomass Bioenergy. 57, 249-263.

[34] Fabry, F., Rehmet, C., Rohani, V., Fulcheri, L., 2013. Waste gasification by thermal plasma: a review. Waste Biomass Valorization. 4(3), 421-439.

[35] Franco, C., Pinto, F., Gulyurtlu, I., Cabrita, I., 2003. The study of reactions influencing the biomass steam gasification process. Fuel. 82(7), 835-842.

[36] Froese, R.E., Shonnard, D.R., Miller, C.A., Koers, K.P., Johnson, D.M., 2010. An evaluation of greenhouse gas mitigation options for coal-fired power plants in the US great lakes states. Biomass Bioenergy. 34(3), 251 262.

[37] Gómez-Barea, A., Leckner, B., Perales, A.V., Nilsson, S., Cano, D.F., 2013a. Improving the performance of fluidized bed biomass/waste gasifiers for distributed electricity: a new three-stage gasification system. Appl. Therm. Eng. 50(2), 1453-1462.

[38] Gómez-Barea, A., Ollero, P., Leckner, B., 2013b. Optimization of char and tar conversion in fluidized bed biomass gasifiers. Fuel. 103, 42-52.

[39] Gomez, E., Rani, D.A., Cheeseman, C.R., Deegan, D., Wise, M., Boccaccini, A.R., 2009. Thermal plasma technology for the treatment of wastes: a critical review. J. Hazard. Mater. 161(2-3), 614-626.

[40] González-García, S., Iribarren, D., Susmozas, A., Dufour, J., Murphy, R.J., 2012. Life cycle assessment of two alternative bioenergy systems involving salix spp. biomass: bioethanol production and power generation. Appl. Energy. 95, 111-122.

[41] Göransson, K., Söderlind, U., He, J., Zhang, W., 2011. Review of syngas production via biomass DFBGs. Renew. Sust. Energy Rev. 15(1), 482492

[42] Gottumukkala, L.D., Haigh, K., Collard, F.X., van Rensburg, E., Görgens, J., 2016. Opportunities and prospects of biorefinery-based valorisation of pulp and paper sludge. Bioresour. Technol. 215, 37-49.

[43] Guest, G., Bright, R.M., Cherubini, F., Michelsen, O., Strømman, A.H., 2011. Life cycle assessment of biomass-based combined heat and power plants. J. Ind. Ecol. 15(6), 908-921.
[44] Guo, Y., Wang, S.Z., Xu, D.H., Gong, Y.M., Ma, H.H., Tang, X.Y., 2010. Review of catalytic supercritical water gasification for hydrogen production from biomass. Renew. Sust. Energy Rev. 14(1), 334-343

[45] Hartmann, D., Kaltschmitt, M., 1999. Electricity generation from solid biomass via co-combustion with coal: energy and emission balances from a German case study. Biomass Bioenergy. 16(6), 397 406.

[46] Heberlein, J., Murphy, A.B., 2008. Thermal plasma waste treatment. J. Phys. D: Appl. Phys. 41(5), 053001.

[47] Heidenreich, S., Foscolo, P.U., 2015. New concepts in biomass gasification. Prog. Energy Combust. Sci. 46, 72-95.

[48] Heidenreich, S., Nacken, M., Foscolo, P.U., Rapagna, S., 2013 Gasification apparatus and method for generating syngas from gasifiable feedstock material. U.S. Patent 8,562,701.

[49] Henrich, E., Dahmen, N., Dinjus, E., 2009. Cost estimate for biosynfuel production via biosyncrude gasification. Biofuels, Bioprod. Biorefin. 3(1), 28-41.

[50] Henriksen, U., Ahrenfeldt, J., Jensen, T.K., Gøbel, B., Bentzen, J.D. Hindsgaul, C., Sørensen, L.H., 2006. The design, construction and operation of a $75 \mathrm{~kW}$ two-stage gasifier. Energy. 31(10-11), 15421553.

[51] Higman, C., Van der Burgt, M., 2011. Gasification. gulf professional publishing.

[52] Hlina, M., Hrabovsky, M., Kavka, T., Konrad, M., 2014. Production of high quality syngas from argon/water plasma gasification of biomass and waste. Waste Manage. 34(1), 63-66.

[53] Houben, M.P., De Lange, H.C., Van Steenhoven, A.A., 2005. Tar reduction through partial combustion of fuel gas. Fuel. 84(7-8), 817 824.

[54] Howaniec, N., Smoliński, A., 2013. Steam co-gasification of coal and biomass - Synergy in reactivity of fuel blends Chars. Int. J. Hydrogen Energy. 38(36), 16152-16160

[55] Hrabovsky, M., Hlina, M., Konrad, M., Kopecky, V., Kavka, T., Chumak, O., Maslani, A., 2009. Thermal plasma gasification of biomass for fuel gas production. High Temp. Mater. Processes. 13(34), 229 .

[56] ISO, I., 2006. 14040: Environmental management-life cycle assessment-principles and framework. London: British Standards Institution.

[57] Jeong, H.J., Park, S.S., Hwang, J., 2014. Co-gasification of coalbiomass blended char with $\mathrm{CO}_{2}$ at temperatures of $900-1100{ }^{\circ} \mathrm{C}$. Fuel 116, 465-470.

[58] Kajitani, S., Zhang, Y., Umemoto, S., Ashizawa, M., Hara, S., 2009 Co-gasification reactivity of coal and woody biomass in hightemperature gasification. Energy Fuels. 24(1), 145-151.

[59] Kalinci, Y., Hepbasli, A., Dincer, I., 2012. Life cycle assessment of hydrogen production from biomass gasification systems. Int. J Hydrogen Energy. 37(19), 14026-14039.

[60] Kamler, J., Andres, J., 2012. Supercritical water gasification of municipal sludge: a novel approach to waste treatment and energy recovery. InTech.

[61] Khoo, H.H., Ee, W.L., Isoni, V., 2016. Bio-chemicals from lignocellulose feedstock: sustainability, LCA and the green conundrum. Green Chem. 18(7), 1912-1922.

[62] Kimming, M., Sundberg, C., Nordberg, A., Baky, A., Bernesson, S. Norén, O., Hansson, P.A., 2011. Biomass from agriculture in smallscale combined heat and power plants-a comparative life cycle assessment. Biomass Bioenergy. 35(4), 1572-1581.

[63] Kirnbauer, F., Wilk, V., Kitzler, H., Kern, S., Hofbauer, H., 2012. The positive effects of bed material coating on tar reduction in a dual fluidized bed gasifier. Fuel. 95, 553-562.

[64] Koroneos, C., Dompros, A., Roumbas, G., 2008. Hydrogen production via biomass gasification-a life cycle assessment approach. Chem. Eng. Process. Process Intensif. 47(8), 1261-1268.

[65] Kruse, A., 2008. Supercritical water gasification. Biofuels, Bioprod. Biorefin. 2(5), 415-437.

[66] Kumar, A., Kumar, N., Baredar, P., Shukla, A., 2015. A review on biomass energy resources, potential, conversion and policy in India. Renew. Sust.Energy Rev. 45, 530-539. 
[67] Lahijani, P., Zainal, Z.A., Mohamed, A.R., Mohammadi, M., 2013. Cogasification of tire and biomass for enhancement of tire-char reactivity in $\mathrm{CO}_{2}$ gasification process. Bioresour. Technol. 138, 124-130.

[68] Leibbrandt, N.H., Aboyade, A.O., Knoetze, J.H., Görgens, J.F., 2013. Process efficiency of biofuel production via gasification and fischertropsch synthesis. Fuel. 109, 484-492.

[69] Leibbrandt, N.H., Knoetze, J.H., Görgens, J.F., 2011. Comparing biological and thermochemical processing of sugarcane bagasse: an energy balance perspective. Biomass Bioenergy. 35(5), 2117-2126.

[70] Li, J., Liu, K., Yan, S., Li, Y., Han, D., 2016. Application of thermal plasma technology for the treatment of solid wastes in China: an overview. Waste Manage. 58, 260-269.

[71] Lu, Y., Guo, L., Zhang, X., Ji, C., 2012. Hydrogen production by supercritical water gasification of biomass: explore the way to maximum hydrogen yield and high carbon gasification efficiency. Int. J. Hydrogen Energy. 37(4), 3177-3185.

[72] Malkow, T., 2004. Novel and innovative pyrolysis and gasification technologies for energy efficient and environmentally sound MSW disposal. Waste Manage. 24(1), 53-79.

[73] Matsumura, Y., Sasaki, M., Okuda, K., Takami, S., Ohara, S., Umetsu, M., Adschiri, T., 2006. Supercritical water treatment of biomass for energy and material recovery. Combust. Sci. Technol. 178(1-3), 509-536.

[74] Matsumura, Y., Minowa, T., Potic, B., Kersten, S.R., Prins, W., van Swaaij, W.P., van de Beld, B., Elliott, D.C., Neuenschwander, G.G., Kruse, A., Antal Jr, M.J., 2005. Biomass gasification in near-and supercritical water: status and prospects. Biomass Bioenergy. 29(4), 269-292.

[75] Molino, A., Chianese, S., Musmarra, D., 2016. Biomass gasification technology: the state of the art overview. J. Energy Chem. 25(1), 10-25.

[76] Moreno, J., Dufour, J., 2013. Life cycle assessment of hydrogen production from biomass gasification. Evaluation of different Spanish feedstocks. Int. J. Hydrogen Energy. 38(18), 7616-7622.

[77] Motycka, S.A., 2013. Techno economic analysis of a plasma gasification biomass to liquids plant. Doctoral dissertation, George Washington University.

[78] Mountouris, A., Voutsas, E., Tassios, D., 2008. Plasma gasification of sewage sludge: process development and energy optimization. Energy Convers. Manageme. 49(8), 2264-2271.

[79] Narobe, M., Golob, J., Klinar, D., Francetič, V., Likozar, B., 2014. Cogasification of biomass and plastics: pyrolysis kinetics studies, experiments on $100 \mathrm{~kW}$ dual fluidized bed pilot plant and development of thermodynamic equilibrium model and balances. Bioresour. Technol. $162,21-29$

[80] Negro, S.O., Suurs, R.A., Hekkert, M.P., 2008. The bumpy road of biomass gasification in the Netherlands: explaining the rise and fall of an emerging innovation system. Technol. Forecasting Social Change. 75(1), 57-77.

[81] Nemanova, V., Abedini, A., Liliedahl, T., Engvall, K., 2014. Cogasification of petroleum coke and biomass. Fuel. 117, 870-875.

[82] Ni, M., Leung, D.Y., Leung, M.K., Sumathy, K., 2006. An overview of hydrogen production from biomass. Fuel Process. Technol. 87(5), $461-$ 472.

[83] Nipattummakul, N., Ahmed, I.I., Kerdsuwan, S., Gupta, A.K., 2010. Hydrogen and syngas production from sewage sludge via steam gasification. Int. J. Hydrogen Energy. 35(21), 11738-11745.

[84] Pa, A., Bi, X.T., Sokhansanj, S., 2011. A life cycle evaluation of wood pellet gasification for district heating in British Columbia. Bioresour. Technol. 102(10), 6167-6177.

[85] Pan, Y.G., Velo, E., Roca, X., Manya, J.J., Puigjaner, L., 2000. Fluidized bed co-gasification of residual biomass/poor coal blends for fuel gas production. Fuel. 79(11), 1317-1326.

[86] Parthasarathy, P., Narayanan, K.S., 2014. Hydrogen production from steam gasification of biomass: influence of process parameters on hydrogen yield-a review. Renew. Energ. 66, 570-579.

[87] Petersen, A.M., Farzad, S., Görgens, J.F., 2015. Techno-economic assessment of integrating methanol or Fischer-Tropsch synthesis in a South African sugar mill. Bioresour. Technol. 183, 141-152.

[88] Pfender, E., 1999. Thermal plasma technology: where do we stand and where are we going?. Plasma Chem. Plasma Process. 19(1), 1-31.

[89] Pinto, F., André, R.N., Franco, C., Lopes, H., Carolino, C., Costa, R., Gulyurtlu, I., 2010. Co-gasification of coal and wastes in a pilot-scale installation. 2: Effect of catalysts in syngas treatment to achieve sulphur and nitrogen compounds abatement. Fuel. 89(11), 3340-3351.

[90] Pinto, F., André, R.N., Franco, C., Lopes, H., Gulyurtlu, I., Cabrita I., 2009. Co-gasification of coal and wastes in a pilot-scale installation. 1: Effect of catalysts in syngas treatment to achieve tar abatement. Fuel. 88 (12), 2392-2402.

[91] Pinto, F., Franco, C., André, R.N., Miranda, M., Gulyurtlu, I., Cabrita I., 2002. Co-gasification study of biomass mixed with plastic wastes. Fuel. 81(3), 291-297.

[92] Pucker, J., Zwart, R., Jungmeier, G., 2012. Greenhouse gas and energy analysis of substitute natural gas from biomass for space heat. Biomass Bioenergy. 38, 95-101.

[93] Puy, N., Rieradevall, J., Bartrolí, J., 2010. Environmental assessment of post-consumer wood and forest residues gasification: the case study of Barcelona metropolitan area. Biomass Bioenergy. 34(10), 1457-1465.

[94] Renó, M.L.G., del Olmo, O.A., Palacio, J.C.E., Lora, E.E.S. Venturini, O.J., 2014. Sugarcane biorefineries: case studies applied to the Brazilian sugar-alcohol industry. Energy Convers. Manage. 86, 981-991.

[95] Ruiz, J.A., Juárez, M.C., Morales, M.P., Muñoz, P., Mendívil, M.A., 2013. Biomass gasification for electricity generation: review of current technology barriers. Renew. Sust. Energy Rev. 18, 174-183.

[96] Ruoppolo, G., Ammendola, P., Chirone, R., Miccio, F., 2012. H2-rich syngas production by fluidized bed gasification of biomass and plastic fuel. Waste Manage. 32(4),724-732

[97] Rutberg, P.G., Bratsev, A.N., Kuznetsov, V.A., Popov, V.E., Ufimtsev, A.A., 2011. On efficiency of plasma gasification of wooc residues. Biomass Bioenergy. 35(1), 495-504.

[98] Saber, E.M., Tham, K.W., Leibundgut, H., 2016. A review of high temperature cooling systems in tropical buildings. Build. Environ. 96, 237-249

[99] Saidur, R., Abdelaziz, E.A., Demirbas, A., Hossain, M.S., Mekhilef, S., 2011. A review on biomass as a fuel for boilers. Renew. Sust. Energy Rev. 15(5), 2262-2289.

[100] Sami, M., Annamalai, K., Wooldridge, M., 2001. Co-firing of coa and biomass fuel blends. Prog. Energy Combust. Sci. 27(2), 171-214.

[101] Samiran, N.A., Jaafar, M.N.M., Ng, J.N., Lam, S.S., Chong, C.T., 2016. Progress in biomass gasification technique - with focus on Malaysian palm biomass for syngas production. Renew. Sust. Energy Rev. 62, 1047-1062.

[102] Sanlisoy, A., Carpinlioglu, M.O., 2016. A review on plasma gasification for solid waste disposal. Int. J. Hydrogen Energy. DOI 10.1016/j.ijhydene.2016.06.008

[103] Savage, P.E., 2009. A perspective on catalysis in sub- and supercritical water. J. Supercrit. Fluids. 47(3), 407-414.

[104] Savolainen, K., 2003. Co-firing of biomass in coal-fired utility boilers. Appl. Energy. 74(3-4), 369-381.

[105] Sekoai, P.T., Daramola, M.O., 2015. Biohydrogen production as a potential energy fuel in South Africa. Biofuel Res. J. 2(2), 223-226.

[106] Sharma, S., Sheth, P.N., 2016. Air-steam biomass gasification experiments, modeling and simulation. Energy Convers. Manage. 110,307-318.

[107] Shrestha, S., Ali, B.S., Hamid, M.B.D., 2016. Cold flow model of dual fluidized bed: a review. Renew. Sust. Energy Rev. 53, 1529 1548 .

[108]Sikarwar, V.S., Zhao, M., Clough, P., Yao, J., Zhong, X., Memon M.Z., Shah, N., Anthony, E., Fennell, P., 2016. An overview of advances in biomass gasification. Energy Environ. Sci. 9, 2939-2977.

[109]Steubing, B., Zah, R., Ludwig, C., 2011. Life cycle assessment of SNG from wood for heating, electricity, and transportation. Biomass Bioenergy. 35(7), 2950-2960.

[110] Stockford, C., Brandon, N., Irvine, J., Mays, T., Metcalfe, I., Book, D., Ekins, P., Kucernak, A., Molkov, V., Steinberger-Wilckens, R., Shah, N., 2015. H2FC SUPERGEN: an overview of the hydrogen and fuel cell research across the UK. Int. J. Hydrogen Energy. 40(15), 5534-5543.

[111] Susmozas, A., Iribarren, D., Zapp, P., Linßen, J., Dufour, J., 2016 Life-cycle performance of hydrogen production via indirect biomass gasification with $\mathrm{CO}_{2}$ capture. Int. J. Hydrogen Energy 41(42), 
19484-19491.

[112] Sutton, D., Kelleher, B., Ross, J.R., 2001. Review of literature on catalysts for biomass gasification. Fuel Process. Technol. 73(3), 155-173.

[113] Svoboda, K., Pohořelý, M., Hartman, M., Martinec, J., 2009. Pretreatment and feeding of biomass for pressurized entrained flow gasification. Fuel Process. Technol. 90(5), 629-635.

[114]Taba, L.E., Irfan, M.F., Daud, W.A.M.W., Chakrabarti, M.H., 2012. The effect of temperature on various parameters in coal, biomass and COgasification: a review. Renew. Sust. Energy Rev. 16(8), 5584-5596.

[115]Tonini, D., Astrup, T., 2012. LCA of biomass-based energy systems: a case study for Denmark. Appl. Energy. 99, 234-246.

[116]Udomsirichakorn, J., Basu, P., Salam, P.A., Acharya, B., 2013. Effect of $\mathrm{CaO}$ on tar reforming to hydrogen-enriched gas with in-process $\mathrm{CO}_{2}$ capture in a bubbling fluidized bed biomass steam gasifier. Int. J. Hydrogen Energy. 38(34), 14495-14504.

[117]Udomsirichakorn, J., Salam, P.A., 2014. Review of hydrogen-enriched gas production from steam gasification of biomass: the prospect of $\mathrm{CaO}$ based chemical looping gasification. Renew. Sust. Energy Rev. 30, 565579 .

[118] Upadhyay, T.P., Shahi, C., Leitch, M., Pulkki, R., 2012. Economic feasibility of biomass gasification for power generation in three selected communities of northwestern Ontario, Canada. Energy Policy. 44, 235244.
[119]Van Oost, G., Hrabovsky, M., Kopecky, M., Konrad, M., Hlina, M., Kavka, T., 2008. Pyrolysis/gasification of biomass for synthetic fuel production using a hybrid gas-water stabilized plasma torch. Vacuum. 83(1), 209-212.

[120]Wei, L., Xu, S., Zhang, L., Liu, C., Zhu, H., Liu, S., 2007. Steam gasification of biomass for hydrogen-rich gas in a free-fall reactor. Int. J. Hydrogen Energy. 32(1), 24-31.

[121]Wu, C., Wang, L., Williams, P.T., Shi, J., Huang, J., 2011. Hydrogen production from biomass gasification with Ni/MCM-41 catalysts: influence of Ni content. Appl. Catal., B. 108, 6-13.

[122] Yin, X., Chang, J., Wang, J., Fu, Y., Wu, C., Leung, D.Y.C., 2004 Exploration of possibility and technical route for methanol synthesis via biomass gasification in China. Coal Convers. 27(3), 17-22.

[123]Zhang, Y., McKechnie, J., Cormier, D., Lyng, R., Mabee, W., Ogino, A., Maclean, H.L., 2009. Life cycle emissions and cost of producing electricity from coal, natural gas, and wood pellets in Ontario, Canada. Environ. Sci. Technol. 44(1), 538-544.

[124]Zinn, E., Thunman, H., 2016. Göteborg Energi: Vehicle fuel from organic waste. Industrial Biorenewables: Practical Viewpoint, A, pp 255-266. 